\title{
Transient postseismic mantle relaxation following 2004 Sumatra earthquake: implications of seismic vulnerability in the Andaman-Nicobar region
}

\author{
C. D. Reddy ${ }^{1}$, S. K. Prajapati ${ }^{2}$, P. S. Sunil ${ }^{1}$, and S. K. Arora ${ }^{3}$ \\ ${ }^{1}$ Indian Institute of Geomagnetism, New Panvel, Navi Mumbai, India \\ ${ }^{2}$ Ministry of Earth Sciences, New Delhi, India \\ ${ }^{3}$ Centre for Earthquake Science Studies and Applications, The Indian Planetary Society, Borivali, Mumbai, India \\ Correspondence to: C. D. Reddy (cdreddy@iigs.iigm.res.in)
}

Received: 29 September 2010 - Revised: 19 December 2011 - Accepted: 19 December 2011 - Published: 27 February 2012

\begin{abstract}
Throughout the world, the tsunami generation potential of some large under-sea earthquakes significantly contributes to regional seismic hazard, which gives rise to significant risk in the near-shore provinces where human settlements are in sizeable population, often referred to as coastal seismic risk. In this context, we show from the pertinent GPS data that the transient stresses generated by the viscoelastic relaxation process taking place in the mantle is capable of rupturing major faults by stress transfer from the mantle through the lower crust including triggering additional rupture on the other major faults. We also infer that postseismic relaxation at relatively large depths can push some of the fault segments to reactivation causing failure sequences. As an illustration to these effects, we consider in detail the earthquake sequence comprising six events, starting from the main event of $M_{\mathrm{w}}=7.5$, on 10 August 2009 and tapering off to a small earthquake of $M_{\mathrm{w}}=4.5$ on 2 February 2011 over a period of eighteen months in the intensely seismic Andaman Islands between India and Myanmar. The persisting transient stresses, spatio-temporal seismic pattern, modeled Coulomb stress changes, and the southward migration of earthquake activity has increased the probability of moderate earthquakes recurring in the northern Andaman region, particularly closer to or somewhat south of Diglipur.
\end{abstract}

\section{Introduction}

An earthquake is a most destructive tectonic process and occurs when there is a sudden release of accumulated elastic strain energy in the Earth's crust. Scholz (2003) provide excellent reading on this subject. In a broad perspective, a big earthquake can trigger another earthquake on secondary faults by static (elastic), dynamic (short-term transient stresses) and postseismic stress transfer phenomena. A detailed review on this subject is provided by Freed (2005). Increase in the static Coulomb stress can bring a fault closer to failure (Stein, 1999; King and Cocco, 2000). Stress associated with fault slip can be computed using an analytical formulation introduced by Okada (1992).

Postseismic relaxation can change the space-time pattern of the stress distribution and of the regional seismicity. Owing to its long-term fluid behavior, the viscoelastic lithosphere, particularly weaker lower crust and upper mantle, cannot sustain coseismic stress changes so that it relaxes viscously causing crustal deformation for months to years (Pollitz, 1992). The nature of postseismic deformation is reviewed by Hearn (2003). Analysis of postseismic deformation provides information on rheological properties of the lower crust and upper mantle. Bürgmann and Dresen (2008) have reviewed approaches to deduce the rheology of the lower crust and upper mantle from experimental, field geologic and geodetic evidences. There are many possible mechanisms by which the postseismic relaxation takes place. These mechanisms include, for example, afterslip (Savage and Svarc, 1997), viscoelastic relaxation (Pollitz, 2001), and poroelastic process (Peltzer et al., 1996). Amongst these mechanisms, the postseismic relaxation through viscoelastic response in lower crust and upper mantle is one that can trigger delayed earthquakes at far away distances.

The studies by Freed and Lin (2001) show that, within a few years following an earthquake, the postseismic stress changes in upper crust can be as large as the stress released by the leading earthquake itself (Xiong et al., 2010; Deng et al., 1999). Monitoring such changes is crucial for characterizing the regional, seismic hazard (Hearn, 2001). Such stress changes in a seismogenic region can be monitored by deploying advanced, space-borne technology such as Global 
Positioning System (GPS), Interferometric Synthetic Aperture Radar (InSAR), and by laser strainmeter, other geodetic and seismological observations. In this paper, we investigate the role of the viscoelastic mantle relaxation (following 2004 Sumatra earthquake) in conjunction with the modeled Coulomb stress changes, $b$-value as functions of time and spatio-temporal seismic pattern in studying the seismic vulnerability in the Andaman-Nicobar region.

\section{Seismotectonic scenarios in Andaman-Nicobar region}

Some of the major geotectonic elements that are considered seismogenic in the near-shore areas of the Indian subcontinent are: the Makran subduction zone of the coast of Pakistan, the western part of the Narmada-Son lineament of Central India, the West Coast fault, Chagos-Laccadive Ridge, Palghat-Cauvery shear zone, the Godavari and Mahanadi grabens and Arakan-Yoma fold belt, the north Bay of Bengal and the Andaman-Nicobar regions. An extension of the active Arakan-Yoma fold belt in the Bay of Bengal constituted by the Andaman-Nicobar Island region shows up as a highly seismic region as evidenced by the $2004 M_{\mathrm{w}}=9.4$ Sumatra earthquake with a fairly high degree of tsunamigenesis. In the light of seismic vulnerability, we discuss the seismotectonics of the highly active Andaman-Nicobar region.

The Andaman-Nicobar region in the Indian Ocean is recognized as one of the most seismically active as well as tsunamigenic regions of the Indian subcontinent (Fig. 1) with the status of highest seismic hazard zone, graded as $\mathrm{V}$ on the seismic zoning map of India (scale of II to V) compiled by the Bureau of Indian Standards (BIS, 2002; Petroy and Wiens, 1989). This region is known to have experienced several damaging earthquakes in the past, some of which have generated tsunami with considerable impact (Zhou et al., 2002; Ortiz and Bilham, 2003; Verma et al., 1978). The subduction tectonics of the Andaman arc region, with regard to characteristics and rates of subduction in the region, have been studied by Dasgupta et al. (2003), Neilsen et al. (2004), Genrich et al. (2000), McCaffrey et al. (2000), Bettinelli et al. (2006), Socquet et al. (2006) and Lay et al. (2005).

Focusing more on the study region, the important tectonic features are the north-south-trending Indo-Burma ranges to the north, Andaman-Nicobar Islands to the south, and the Sumatra fault system to the southeast. In the back arc region (Fig. 1a), the inner volcanic arc forms a north-south trending belt of discontinuous submarine ridges consisting of volcanic seamounts (Mukhopadhyay, 1984). The Barren and Narcondam volcanoes are considered important components of this system; the former is still active and the later is now extinct. The region between the Andaman-Nicobar Islands and the volcanic ridge is the foredeep sedimentary trough (Dickinson and Seely, 1979). Between the AndamanNicobar islands and volcanic ridge is the West Andaman Fault (WAF) (Fig. 1a), which is most prominent among the

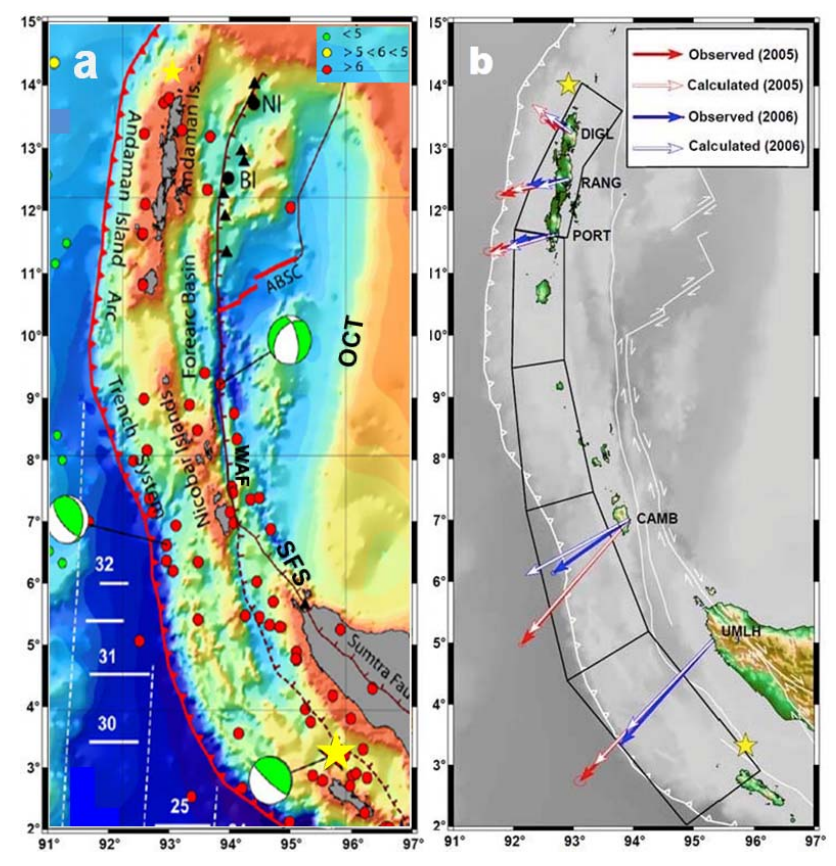

Fig. 1. (a): Tectonic map of the Andaman-Nicobar-Sumatra region superposed on the topography and bathymetry. Andaman arc-trench system, Andaman back arc spreading center (ABSC), Ocean Continental Transition (OCT), West Andaman Fault (WAF) and Sumatra Fault System (SFS) are shown. Black filled circles represent Narcondam (NI) and Barren (BI) island volcanoes. Yellow stars indicate locations of the 26 December 2004 Sumatra earthquake (bottom) and that of 10 August 2009 at Diglipur (top). Beachball symbols represent the fault plane solutions for selected events. E-W lines are magnetic lineations and numbers indicate corresponding magnetic anomalies (Subrahmanyam et al., 2008). (b): Comparison of postseismic observed (reckoned from GPS) and calculated surface velocities associated with the 2004 Sumatra-Andaman earthquake. The five areas marked by quadrilaterals along the AndamanSumatra subduction zone indicate assumed coseismic fault plane used for modeling postseismic deformation (Reddy et al., 2009).

thrust fault systems of the Andaman-Nicobar Islands. Kayal et al. (2004) investigated the aftershocks of the 13 September 2002 Diglipur earthquake $\left(M_{\mathrm{w}}=6.5\right)$, all of which were confined to the north Andaman, and inferred that there exists a transverse seismogenic structure to the north of Andaman Islands.

The 26 December 2004 Sumatra-Andaman earthquake $\left(M_{\mathrm{w}}=9.3\right)$ facilitated studies of the rupture process, propagation of the main shock and aftershocks, coseismic and postseismic deformation and rheology in this region (Ammon et al., 2005; Banerjee et al., 2007; Pollitz et al., 2006; Reddy et al., 2010). For developing a comprehensive model involving earthquake and volcanic hazard in this region, Mishra et al. (2007) used the local seismic network and studied a large number of aftershocks of the 2004 Sumatra-Andaman earthquake and looked into some of its seismotectonic implications. They inferred that the Baratang 
mud volcano (Mishra et al., 2007; Manga et al., 2009) region is mainly associated with a thrust faulting mechanism at depths of 0-30 km suggesting a high compressive force beneath, while the region of Barren and Narcondum volcanoes exhibit dominantly normal faulting due to tensional forces that suggest brittle failure in the weakened crust (Mishra et al., 2007). The sequence of earthquakes north of Diglipur comprising six events (Table 3 ), starting from the main event of $M_{\mathrm{w}}=7.5$ on 10 August 2009 and tapering off to a small earthquake of $M_{\mathrm{w}}=4.5$ on 2 February 2011 (hereafter referred as Diglipur earthquakes), indicates the seismic potentiality of this region after the 26 December 2004 Sumatra earthquake.

\section{GPS data collection and modeling}

Following the 2004 Sumatra-Andaman earthquake, an array of GPS sites was promptly established in the Andaman and Nicobar region (Reddy et al., 2009). We used both Leica and Trimble receivers with choke ring antennas, and at each site the data have been collected with a fixed sampling interval of $30 \mathrm{~s}$ and tracking satellites above $15^{\circ}$ elevations. This GPS network facilitated obtaining near field displacement field during 2005-2008. We removed the annual and semi-annual periodic terms from the position time series, as explained by Dong et al. (2002). Figure 2 shows the postseismic transients in horizontal (east and north) components obtained from the GPS measurements taken in campaign mode during the period 2005-2008, and Table 1 gives the corresponding details of the observed data of postseismic velocity (ITRF2005) for these components. We discarded the first six months of data so as to avoid the postseismic relaxation contribution from poroelastic and afterslip mechanisms (Kreemer et al., 2006). We performed the exponential fitting for the time series (Fig. 2) assuming that postseismic relaxation is governed by viscoelastic mechanism.

To investigate the contribution of postseismic deformation due to viscoelastic relaxation, we adopted the semi-analytical approach by Pollitz, 1997 (VISCO1D), considering stratified Earth model and coseismic fault plane solution (Reddy et al., 2010). The layered- Earth model parameters (shear modulus, bulk modulus and density) are based on PREM (Dziewonski and Anderson, 1981) which shows three major discontinuities at depths of $65 \mathrm{~km}$ (TL), $220 \mathrm{~km}$ (UM1) and $660 \mathrm{~km}$ (UM2) (Table 2). We kept viscosity constant between discontinuities. The modeling was carried out confined to normal mode theory at high spatial resolution. In the normal mode approach, the spheriodal and toroidal components of the equilibrium are expanded in spherical harmonics (Phinney and Burridge, 1973). For earthquake sources, both spheriodal and toroidal components of the normal mode solution are propagated through multilayered, self-gravitating, viscoelastic Earth model (Pollitz et al., 2006). The modeled and observed postseismic velocities are shown in Fig. $1 b$.

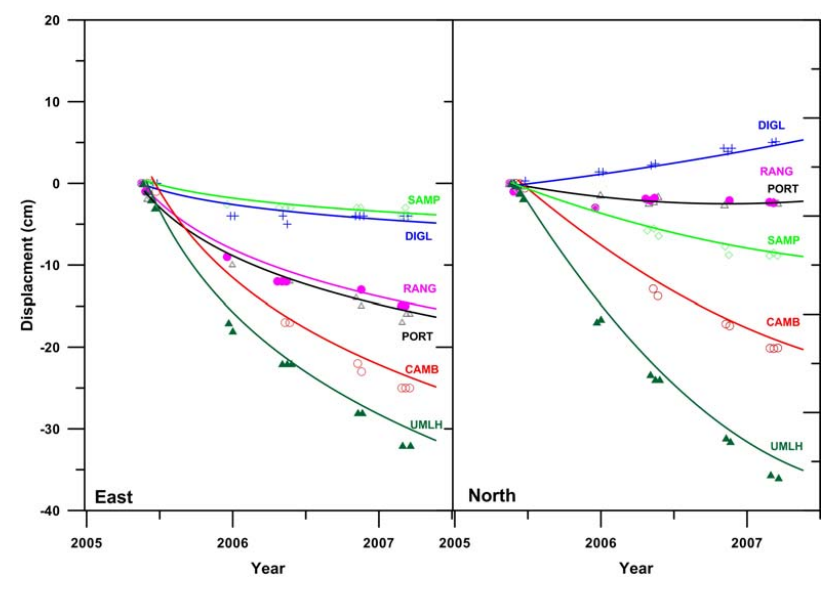

Fig. 2. Postseismic transients in horizontal (east and north) components at six GPS sites: DIGL, RANG, PORT, CAMB, UMLH and SAMP. Four sites (except UMLH and SAMP) are located in the Andaman and Nicobar region as shown in Fig. 1. The solid lines are exponential fits to the observed data points of the postseismic transients.

\section{Estimation of Coulomb stress}

The estimation of Coulomb stress is based on faulting characteristics (strike/dip/rake), slip of the fault, and apparent coefficient of friction in the crust (Aki and Richards, 2002). Since it is difficult to estimate the absolute value of stress on a fault at a given time, the variation of stress is commonly quantified by Coulomb failure function $\left(\Delta \sigma_{\mathrm{f}}\right)$ on the plane of fixed orientation and mechanism by the following relation:

$\Delta \sigma_{\mathrm{f}}=\Delta \tau_{\mathrm{s}}+\mu\left(\Delta \sigma_{\mathrm{n}}-\Delta P\right)$

where $\Delta \tau_{\mathrm{s}}$ is the static stress change, $\Delta \sigma_{\mathrm{n}}$ is the normal stress change (positive if tensile), $\mu$ is the static coefficient of friction and $\Delta P$ (not considered in this study) is the pore pressure change (Stein et al., 1992). Further, interplay between the Coulomb stress and time dependent evolution of frictional properties of faults explains how an earthquake can be triggered within a short interval of time from days to months after the occurrence of a large earthquake and that at some hundred kilometers away from it (Hearn, 2001).

In addition to coseismic Coulomb stress, viscous flow in the lower crust through upper mantle can also increase stress and strain in the seismogenic upper crust, causing it eventually to become the main layer to store strain energy for a future earthquake (Deng et al., 1999). The 26 December 2004 earthquake and recent north Andaman earthquakes provide a unique opportunity to investigate the detailed processes of postseismic stress transfer due to viscoelastic relaxation and earthquake triggering for which ample seismological, geological and geodetic constraints are available.

Following the December 2004 major earthquake, regional surface deformation has been mapped in the AndamanNicobar region using GPS measurements (Paul et al., 2007; 
Table 1. Postseismic velocity (ITRF2005) in all the three components: east $\left(V_{\mathrm{E}}\right)$ and north $\left(V_{\mathrm{N}}\right)$ for the postseismic transients shown in Fig. 2. The additional six sites on the Indian plate (marked by *) are used for constraining the GPS stations shown in Fig. 2.

\begin{tabular}{lllllll}
\hline $\begin{array}{l}\text { GPS } \\
\text { sites }\end{array}$ & $\begin{array}{l}\text { Long. } \\
(\text { deg. }\end{array}$ & $\begin{array}{l}\text { Lat. } \\
(\text { deg. })\end{array}$ & $\begin{array}{l}V_{\mathrm{E}} \\
\left(\mathrm{mm} \mathrm{yr}^{-1}\right)\end{array}$ & $\begin{array}{l}V_{\mathrm{N}} \\
\left(\mathrm{mm} \mathrm{yr}^{-1}\right)\end{array}$ & $\begin{array}{l}\sigma V_{\mathrm{E}} \\
(\mathrm{mm})\end{array}$ & $\begin{array}{l}\sigma V_{\mathrm{N}} \\
(\mathrm{mm})\end{array}$ \\
\hline DIGL & 92.970 & 13.242 & -43.92 & 29.20 & 1.21 & 0.90 \\
RANG & 92.936 & 12.506 & -117.82 & -13.26 & 1.49 & 1.08 \\
PORT & 92.709 & 11.628 & -109.96 & -21.87 & 1.34 & 0.99 \\
CAMB & 93.932 & 7.014 & -178.50 & -140.15 & 1.58 & 1.10 \\
UMLH & 95.339 & 5.053 & -218.54 & -244.46 & 1.44 & 0.95 \\
SAMP & 98.715 & 3.622 & -35.89 & -57.48 & 1.57 & 1.02 \\
*NAGP & 79.046 & 21.144 & 34.75 & 34.64 & 2.41 & 2.04 \\
*HYDE & 78.551 & 17.417 & 40.41 & 34.90 & 0.88 & 0.69 \\
*IISC & 77.570 & 13.021 & 41.63 & 35.44 & 0.72 & 0.56 \\
*TNVL & 77.812 & 8.674 & 46.76 & 35.44 & 1.44 & 1.03 \\
*MALD & 73.526 & 4.189 & 52.54 & 35.75 & 1.90 & 1.69 \\
*DGAR & 72.370 & -7.27 & 46.12 & 32.98 & 0.66 & 0.73 \\
\hline
\end{tabular}

Table 2. Rheological parameters for layered Earth model. TL is top layer including the crust, UM1 is upper mantle Part 1, UM2 is upper mantle Part 2 and LM is lower mantle.

\begin{tabular}{lrrrr}
\hline Layer & $\begin{array}{r}\text { Depth } \\
(\mathrm{km})\end{array}$ & $\begin{array}{r}\text { Density } \\
\left(\mathrm{kg} \mathrm{m}^{1}\right)\end{array}$ & $\begin{array}{r}\text { Shear Modulus } \\
(\mathrm{Pa})\end{array}$ & $\begin{array}{r}\text { Viscosity } \\
(\mathrm{Pas})\end{array}$ \\
\hline TL & $0-65$ & $2.600-3.500$ & $2.5-5.6 \times 10^{10}$ & $1.0 \times 10^{29}$ \\
$\mathrm{UM} 1$ & $65-220$ & $3.500-3.900$ & $6.8000 \times 10^{10}$ & $3.5 \times 10^{19}$ \\
UM2 & $220-660$ & $3.900-4.500$ & $20.000 \times 10^{10}$ & $3.0 \times 10^{20}$ \\
LM & $660-2900$ & $4.500-5.600$ & $22.000 \times 10^{10}$ & $1.5 \times 10^{21}$ \\
\hline
\end{tabular}

Gahalaut et al., 2006; Reddy et al., 2010). There is possibility of a host of mechanisms involved in postseismic deformation after this great earthquake. However, on a short time scale (a few months to about a year), the postseismic relaxation is attributed to afterslip mechanism (Chlieh et al., 2007.), and it can be explained mainly by viscous flow in the upper mantle over a longer period of time (Pollitz et al., 2006; Paul et al., 2007; Reddy et al., 2009).

To model the Coulomb stress associated with the 26 December 2004 earthquake, we used the coseismic fault derived by geodetic inversion (Banerjee et al., 2007) and seismic waveform inversion (Rhie et al., 2007). To constrain viscosity of the upper mantle layer, we used the observed surface deformation following the 2004 event. For the upper mantle flow model, the calculated best fitting viscosity value over the years $2005-2008$ is in the range of $3.0 \times 10^{18}$ to $4.5 \times 10^{19} \mathrm{Pas}$ with an elastic thickness of $65 \mathrm{~km}$. Apparently, the 2004 earthquake caused positive, postseismic stress changes arising due to viscoelastic relaxation process in the Andaman region, whereas none of the regional faults had any negative stress change. The rate of such stress migration depends directly on the viscous flow in the upper mantle beneath the Andaman region. If the upper mantle is viscous and thus unable to sustain this stress load during four years (2004-2008) following the 2004 event, this deep lobe of postseismic stress increase must migrate into the brittle crust as the upper mantle relaxes (Lin and Freed, 2004). Although this increase in postseismic stress due to viscous flow in the northern part of the Andaman region is $<0.1 \mathrm{MPa}$ during the period 2005-2008 (Fig. 3, top), the combined i.e. coseismic and postseismic stress changes (Fig. 3, bottom) are substantially large ( $>0.3 \mathrm{MPa})$.

In the present study, we calculated the Coulomb stress corresponding to four Diglipur earthquakes: $M_{\mathrm{w}}=7.5$, $M_{\mathrm{w}}=6.6, M_{\mathrm{w}}=6.0$ and $M_{\mathrm{w}}=5.4$ events of August 2009, March 2010, June 2010 and August 2010, respectively (see Fig. $4 \mathrm{a}, \mathrm{b}, \mathrm{c}$, and d), considering the coseismic fault parameters (Table 3 ) and coefficient of friction taken as $\sim 0.4$ for the all the four events mentioned here.

We analyzed the trend relationship between the variation of seismicity and stress changes and found that the seismicity rate rises when stress increases, and it diminishes as the stress level reduces, following a major stress drop. Such a trend of decreasing seismicity rate with reducing stress can be seen through the panels from (a) to (d) in Fig. 4. Both the increase and decrease in seismicity rate are followed by a timedependent recovery of stress, which makes it interesting to investigate further. A similar scenario of stress regime is also encountered, for example, in the case of the aftershocks sequence of the 1987, $M_{\mathrm{w}}=6.6$ California earthquake, which shows a significant stress increase $(>0.01 \mathrm{MPa})$ during the period of $2.8 \mathrm{yr}$ after the main event of 1987 (see, also, Stein, 1999). 

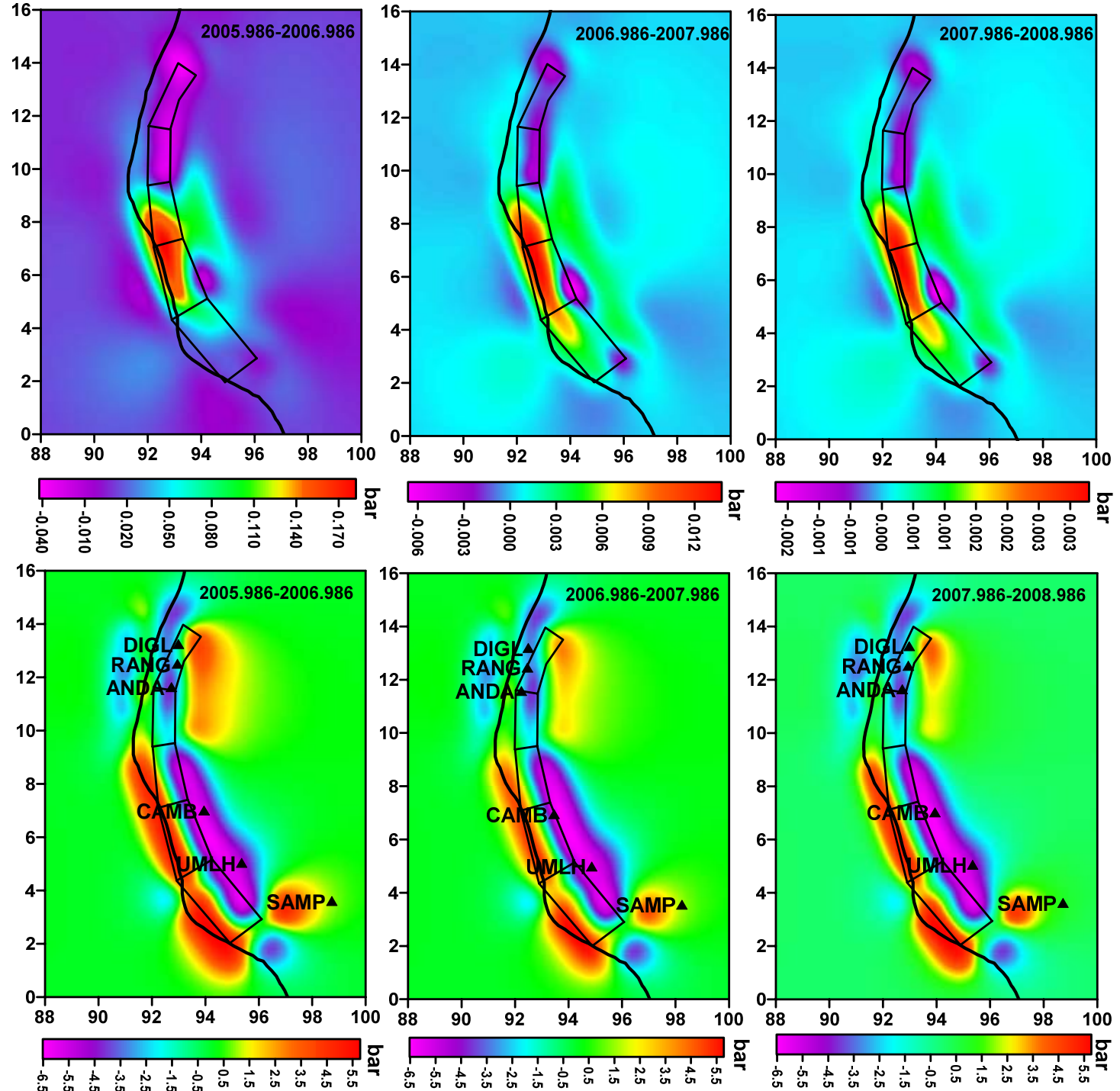

Fig. 3. Top panel gives postseismic stress changes (only viscoelastic) during the period 2005-2008, while the bottom panel gives changes in the combined stress (both viscoelastic and elastic) due to the 26 December 2004 megathrust earthquake.

Table 3. Location, magnitude and fault parameters of six Diglipur earthquakes ranging in magnitude from $M_{\mathrm{W}}=7.5$ to $M_{\mathrm{W}}=4.5$, which occurred between 10 August 2009 (main event) and 2 February 2011. A dash (-) in the columns of the table implies non-availability of the pertinent information.

\begin{tabular}{lccccrrrrrr}
\hline Date & $\begin{array}{r}\text { Lon } \\
\left({ }^{\circ} \mathrm{E}\right)\end{array}$ & $\begin{array}{l}\text { Lat }) \\
\left({ }^{\circ} \mathrm{N}\right)\end{array}$ & $M_{\mathrm{w}}$ & $\begin{array}{r}\text { Depth } \\
(\mathrm{km})\end{array}$ & $\begin{array}{r}\text { Strike } \\
(\mathrm{deg})\end{array}$ & $\begin{array}{r}\text { Length } \\
(\mathrm{km})\end{array}$ & $\begin{array}{r}\text { Width } \\
(\mathrm{km})\end{array}$ & $\begin{array}{c}\text { Dip } \\
(\mathrm{deg})\end{array}$ & $\begin{array}{r}\text { Rake } \\
(\mathrm{deg})\end{array}$ & $\begin{array}{r}\text { Seismic moment } \\
(\text { dyne-cm })\end{array}$ \\
\hline $10-08-09$ & 92.89 & 14.10 & 7.5 & 22.0 & 39 & 104 & 40 & 36 & -92 & $1.95 \times 10^{27}$ \\
$30-03-10$ & 92.83 & 13.67 & 6.6 & 34.0 & 255 & 34 & 12 & 60 & -20 & $1.13 \times 10^{26}$ \\
$18-06-10$ & 93.09 & 13.24 & 6.0 & 20.0 & 116 & 15 & 8 & 38 & 59 & $8.76 \times 10^{24}$ \\
$09-08-10$ & 92.76 & 13.54 & 5.4 & 32.0 & 250 & 6 & 4 & 45 & -28 & $9.16 \times 10^{23}$ \\
$09-12-10$ & 92.57 & 13.12 & 4.9 & 33.0 & - & - & - & - & - & \\
$02-02-11$ & 93.02 & 13.84 & 4.5 & 31 & - & - & - & - & - & \\
\hline
\end{tabular}



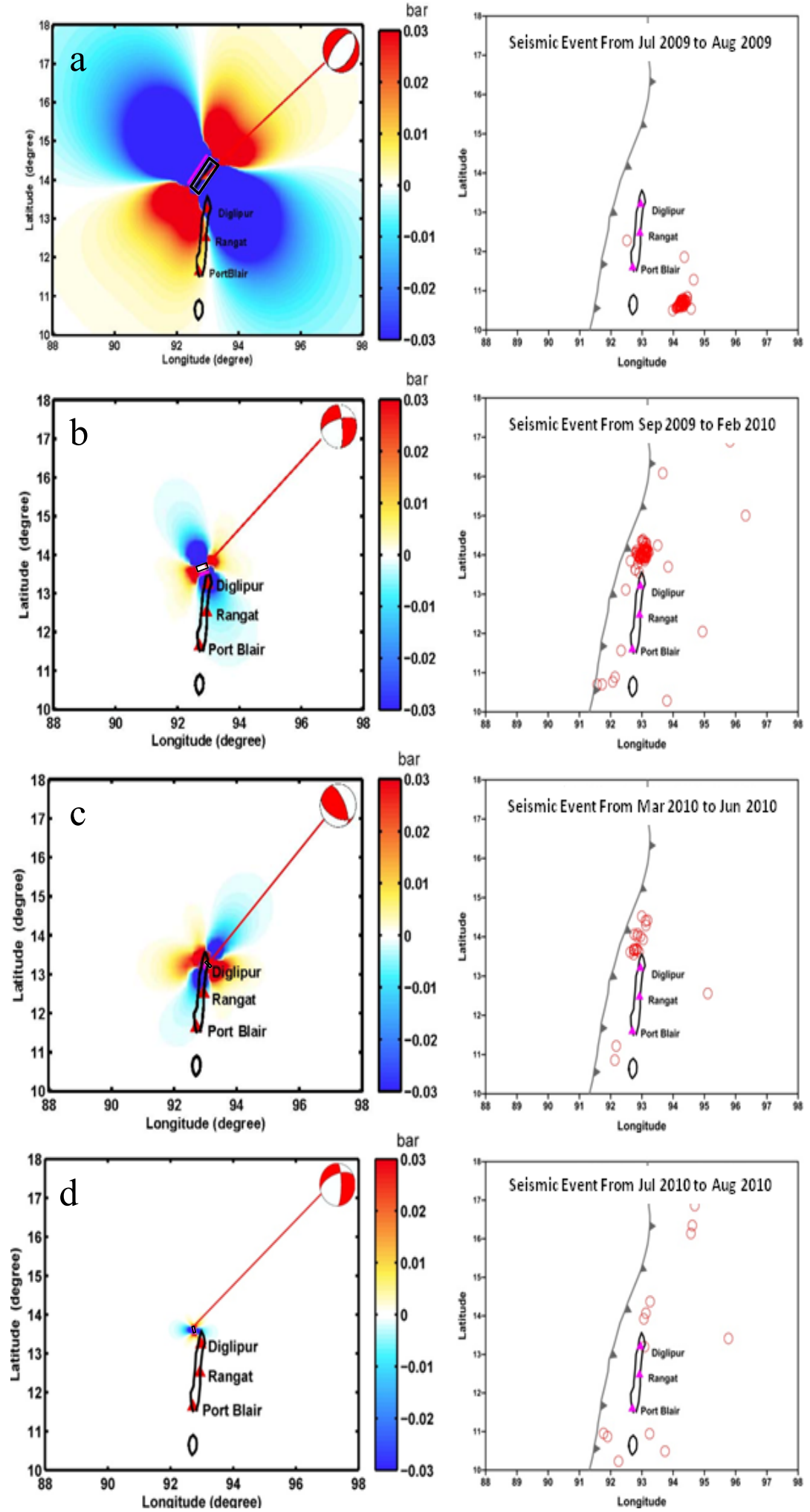

Fig. 4. The left side panels give Coulomb stress change for the four Diglipur earthquakes that occurred on (a) 10 August 2009 , (b) 30 March 2010, (c) 18 June 2010 and (d) 9 August 2010 indicated by stars. The fault parameters are shown in Table 3 . Beach ball symbols indicate fault plane solutions for each of those earthquakes. The corresponding right side panels show the distribution of aftershocks illustrated by red circles; the black line indicates the subduction zone boundary. 


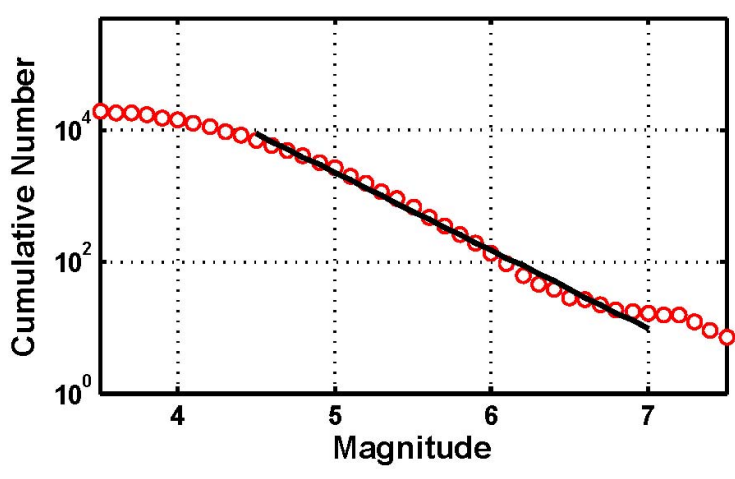

Fig. 5. Best fitting, least-squares line though the IRIS catalogued (http://www.iris.edu/hq/retm) earthquake data set (January 2005 to December 2009), plotting cumulative number of earthquakes against Magnitude to estimate $b$-value in accordance with the G-R relation.

\section{Stress status supported by $b$-value}

The Gutenberg-Richter (G-R) relation (Gutenberg and Richter, 1944) between earthquake magnitude and frequency of occurrence in a given region $(\log N=a-b M$, where $N$ is the cumulative number of events of magnitude $M$ and above, and $a$ and $b$ are constants) allows us to the examine seismic status of that region vis-à-vis the stress changes though the value of the slope $b$ (see, for example, Schorlemmer et al., 2005). For the northern Andaman region, we took the earthquake data set from Incorporated Research Institutions for Seismology (IRIS) catalogue (http://www.iris.edu/hq/retm), widely ranging in magnitude from 2.0 to 8.1 of the earthquakes that occurred over the period of $\sim 5 \mathrm{yr}$ (January 2005 to December 2009), and estimated the $b$-value. Clamping the lower and upper cut-off magnitudes at 4.5 and 7.0, respectively, in order to maintain linearity of the earthquake recurrence G-R relation, the weighted least-squares regression gave $b$-value of $0.984 \pm 0.07$ (Fig. 5). In order to overcome some uncertainties in the estimation of $b$-value by least-squares due mainly to possible incompleteness of earthquake data set, we attempted to evaluate $b$ by maximum likelihood approach (Lombardi, 2003). This gave $b$-value at $1.07 \pm 0.036$, which is in close agreement with that obtained by the least-squares method.

At this stage, we considered it appropriate to examine the stress status indicator $b$-value as a function of time since January 2005. It is marked by a large stress drop due to the 28 March 2005 Nias earthquake of $M_{\mathrm{W}}=8.7$ in this broad region at time when it was most critically stressed. This feature is exhibited in Fig. 6 through a substantial rapid rise in $b$ value above the background to more than a high of 1.8 in the early part of the year 2005 soon after the earthquake. Thereafter, it tended to fall steadily indicating a sharp beginning of another cycle of stress build-up. However, after 2007, the $b$-value distinctly continued to decrease steadily to below 1.0

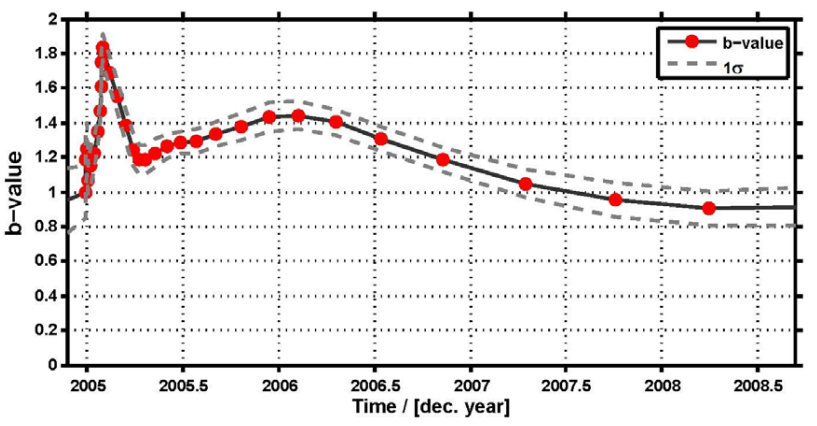

Fig. 6. Temporal variation of $b$-value (thick line) in the Andaman arc region through a period from 2004 until 2009. The dashed line on either side of the thick line corresponds to one standard deviation ( $\sigma=1$ s.d.) in the $b$-value estimates.

until at least 2009. This behavior strongly supports the view that the Andaman arc region containing also the Nias rupture zone is believed to be undergoing positive stress change, which presents a scenario in which occurrence of moderately large earthquakes in the region is quite probable.

\section{Results and discussion}

Stress perturbations following an earthquake modify the insitu stress field, cause frictional instabilities, and can trigger another earthquake by static, dynamic or postseismic relaxation processes which add up additional stress to a fault system that is near failure and could initiate a rupture process which might not have otherwise been ready to nucleate (Wang and Kumpel, 2003). Among the above mentioned processes, the postseismic deformation process does not induce release of the whole of the stored seismic energy; it plays an important role in the redistribution of stress within the seismogenic part of the crust facilitating generation of earthquakes. To characterize the temporal evolution of stress on a fault during postseismic relaxation period, one must constrain both the deformation through time near the fault and the rheology of the layered lithosphere, from its upper brittle crustal section to its deeper ductile part. During this period, the stress applied to the fault is not evenly distributed depth-wise, concentrating in either the shallower part of the lithosphere or at a greater depth as the case may be. This results in a variation in the elastic strain rate distribution and, therefore, in surface geodetic velocities at short and intermediate distances from the fault, which can be observed by space-borne geodetic measurements, such as GPS and InSAR.

Following the 2004 Sumatra earthquake, we made GPS measurements in the Andaman-Nicobar region and modeled the surface postseismic transients due to viscoelastic relaxation. It should be noted that the two other processes, viz poroelastic and afterslip mechanisms, may have been acting concurrently in triggering the earthquake. However, we rule 
out these two processes for the following reasons. Poroelastic transients have very small spatial extent (confined to epicentral region) and can last only 1-2 months (Jónsson et al., 2003). Depending on permeabilities, however, this spatial extent may vary largely (Hughes et al., 2010). On the other hand, the spatial extent of afterslip transients is confined to within 1-2 fault lengths and thus may not play a significant role in certain zones with younger (recently activated) faults (Jónsson, 2008). As far as the Diglipur earthquakes are concerned, they are sufficiently far away $(\sim 1400 \mathrm{~km})$ from the source of the 2004 Sumatra earthquake, although relatively close to the coseismic rupture plane (Figs. 1 and 3), so that the time lag of approximately $4 \mathrm{yr}$ is well beyond the temporal extent of the two above- mentioned processes, which justifies discarding the role of both poroelastic and afterslip mechanisms.

We explored a range of elastic thickness values and viscosities for the upper mantle and obtained the rheology that best simulates the observed surface GPS transients. Using an iterative approach, we determined the rms misfit between the observed and calculated horizontal displacements from the grid obtained by plotting elastic plate thickness as a function of upper mantle viscosity. Among a host of possible combinations, we picked out the appropriate values of elastic thickness and viscosity that correspond to the minimum rms error which best correlates the observed horizontal displacements. As shown in Table 2, the optimal fit for elastic thickness was found to be $65 \mathrm{~km}$, and the corresponding viscosity in the underlying upper mantle was estimated at $3.5 \times 10^{19} \mathrm{Pas}$. As far as the upper mantle viscosity estimates for the subduction zone are concerned, our findings (Table 2) are in agreement with those characterizing the regions of some of the megathrust earthquakes in the world, viz. Chile 1960 (Hu et al., 2004) and Ecuador-Columbia subduction zone (Scott et al., 2003) . The effectiveness of viscoelastic relaxation of the lithosphere for triggering moderately large earthquakes was also demonstrated by a statistical correlation between land (intraplate) and trench (interplate) earthquakes in northern Honshu, Japan (Rydelek and Sacks, 1988, 1990).

The Diglipur earthquake occurred $4.7 \mathrm{yr}$ after the 26 December 2004 Sumatra earthquake. During this period, viscoelastic relaxation of the upper mantle seems to have continuously increased the stress in the crust until it exceeded the threshold triggering this earthquake. To explain this delay $(4.7 \mathrm{yr})$, we argue that the postseismic deformation by viscoelastic relaxation in the upper mantle results in timedependent stress redistribution. After the 2004 Sumatra earthquake, as suggested by Freed (2005) in the case of the 1999 Hector Mine earthquake following the 1992 Landers earthquake, the lower crust in the region gradually began to relax and the stored elastic strain became systematically transferred upwards to the seismogenic upper crust, leading to increased stresses there that eventually produced failure in the faults in the vicinity. Arguing further, there can be either a positive or negative stress change depending on the nature of a fault. For example, in the case of a strike-slip fault, a region showing a tendency to undergo coseismic increase in stress gets systematically further stressed (positive change) whereas that with a negative stress status gets further destressed (negative change). On the other hand, for thrust and normal faults, the viscous relaxation process generally causes stress loading just the other way round, as compared to the case of strike slip fault stated above (Freed and Lin, 1998; Nostro et al., 2001). After an earthquake, the lower crust gradually relaxes its grip on the upper crust, allowing the upper crust to continue deforming in a directional sense consistent with the coseismic deformation (Hearn, 2001). Within a few years, the postseismic deformation becomes mature enough to deliver stress in the upper crust to the extent that it is at least as much as the stress released by the last earthquake in the sequence (Freed and Lin, 2001). In fact, Freed and Burgmann (2004) and Freed et al. (2007) have argued in favour of mostly mantle relaxation that dominates the postseimic relaxation.

Simulations of postseismic stress diffusion by Casarotti and Piersanti (2003) suggest that postseismic viscoelastic relaxation of the mantle can load the elastic lithosphere by stresses up to $1 \mathrm{MPa}$ in a wide area for asthenospheric viscosity of $10^{19} \mathrm{Pas}$ and a lithospheric thickness of $80 \mathrm{~km}$. King et al. (1994) showed that the $1992 M_{\mathrm{w}}=7.3$ Landers earthquake caused a static stress change of $0.02-0.03 \mathrm{MPa}$ in areas $\sim 100 \mathrm{~km}$ away from the earthquake source, and suggest that a stress of even $<0.05 \mathrm{MPa}$ is sufficient to trigger (or to suppress) an earthquake. As seen from Table 2, since viscoelastic modeling of the Andaman region yielded viscosity of the order of $10^{19} \mathrm{Pas}$ and elastic thickness of $65 \mathrm{~km}$, this rheology can generate stress of $\sim 1 \mathrm{MPa}$, which is significantly greater in magnitude than the annual stress change induced by steady interseismic loading. It is contended that stress variation due to the viscoelastic relaxation process increased the probability of occurrence of moderate earthquakes in the region north of Diglipur. Coincidently, Guilbert et al. (2005) found that the rupture due to 2004 Sumatra earthquake propagated more than $1200 \mathrm{~km}$ and its northern extent terminating at $\sim 14^{\circ} \mathrm{N}$ i.e. at the northern end of the Andaman Islands.

The Diglipur earthquake region experienced much faster relaxation as seen by the postseismic geodetic velocity at DIGL (Fig. 2). In this region, the postseismic stress is almost completely relaxed and is presently tending to catch up with interseismic phase, while the other sites, south of DIGL, are still undergoing postseismic relaxation. A regional electrical conductance map of the Andaman-Nicobar region also indicates high conductivity anomaly towards the eastern and north-western margins of the DIGL region (Subba Rao, 2008). This anomaly has been attributed to highly conducting metasediments and mid-crustal conductivity derived from the volcanic arc (e.g. Barren Island). Recently, it has been well established that there is a good correlation between seismicity and electrical conductivity due to the presence of free fluid phase, based on a study carried by 
Arora and Reddy (2001) for the Indian sub-continent. The positive conductivity anomaly north of DIGL corroborates well the occurrence of large shallow seismic events in the region, which renders the northern Andaman region highly vulnerable to moderately large earthquakes.

It is clearly seen from Fig. 4 (see, also, Table 3) that, while a wide area has undergone stress change for the first earthquake (10 August 2009) in the Diglipur sequence, it is significantly narrowed down for the third one (18 June 2010). This trend, as it also appears from the occurrence pattern, is consistent with a systematic decrease in magnitude of these earthquakes, i.e. from 7.5 on 10 August 2009 (main event) to the small earthquake of Magnitude 4.5 (tail event) that followed most recently on 2 February 2011. Interestingly, the earthquake source locations have also progressively moved southward closer to Diglipur. Such a pattern of these earthquakes indicates that this region is not able to sustain extremely large stress for the present thereby producing lower stress drops rather frequently.

The $M_{\mathrm{w}}=7.510$ August 2009 Diglipur earthquake in northern Andaman was probably favored by stress changes during the five years prior to the earthquake. We have investigated the possible role of the 26 December 2004 great earthquake and its postseismic deformation in promoting the 10 August 2009 event and its two episodic successors. We modeled the viscoelastic effect of the 2004 SumatraAndaman earthquake and simulated the stress transfer from the upper mantle to the brittle crust in the five years following the earthquake. Our calculation revealed that the viscous flow in the upper mantle caused postseismic stress increase of $\sim 0.1 \mathrm{MPa}$ near Diglipur, which may have advanced the occurrence of major earthquakes in 2009-2010 in northern Andaman. Furthermore, we studied the Coulomb stress changes pertaining to the sequence of three major earthquakes (10 August 2009, 30 March 2010 and 18 June 2010) that occurred in the northernmost part of the Andaman region. The fault rupture parameters including faulting characteristics and slip corresponding to the above three earthquakes were constrained by Global Centroid Moment Tensor solution (http://www.globalcmt.org). The results indicate (Fig. 3) that the north Andaman earthquake sequence has caused significant stress changes in the region which play a potentially important role of stress transfer in the process of earthquake triggering.

We found that all the earthquakes succeeding the $10 \mathrm{Au}-$ gust 2009 earthquake were promoted by positive stress change and catalysed by the preceding events. However, the static stress does not seem to largely govern the occurrence of the northern Andaman events. On the other hand, the postseismic viscoelastic relaxation process seems to play a more significant role in stress transfer in causing larger events. The results discussed in this paper show some sort of relationship between stress accumulation, stress transfer, and earthquake occurrence pattern. The persisting transient stresses, spatiotemporal seismic pattern, modeled Coulomb failure stress changes, and southward migration of earthquake sources are all suggestive of future probable earthquakes in the northern Andaman region, particularly closer to or somewhat south of Diglipur.

\section{Conclusions}

Earthquakes seem to interact with each other regionally by several physical processes, most prominent among them being triggering though stress transfer in a given tectonic block. There are three possible modes of stress transfer governing the mechanism in which one earthquake prompts or triggers another. These are static stress transfer, dynamic transfer, and postseismic relaxation. The viscoelastic postseismic relaxation process is capable enough to load a neighboring fault causing a second major earthquake. We have demonstrated that the viscoelastic model that best simulates the GPS measured postseismic transients in the AndamanNicobar region can be used to assess the coastal seismic hazards. The model parameters discussed are conducive for sustained postseismic relaxation and facilitate delayed triggering of an earthquake. It is conjectured that the Diglipur earthquake sequence of six events from $M_{\mathrm{W}}=7.5$ (main event) to $M_{\mathrm{w}}=4.5$ (tail event) which struck off the Andaman Islands may well be a manifestation of viscoelastic relaxation which redistributed the stress in the region and produced the earthquakes. From the spatio-temporal seismic pattern of the ongoing earthquakes activity vis-à-vis the regional stress distribution behaviour, it appears that the northern Andaman region, particularly in the southern vicinity of Diglipur, seems to be vulnerable to moderate seismic hazards.

Acknowledgements. We thank Mr. Rishikesh, Mr. Rajbabu and Mr. Bhadra of DST, Port Blair for providing local logistics. Teruyuki Kato provided GPS receivers during the initial phase of the GPS data collection which is gratefully acknowledged. We thank Roland Burgmann and anonymous reviewers for their critical comments which significantly improved the manuscript.

Edited by: M. E. Contadakis

Reviewed by: R. Burgmann and two other anonymous referees

\section{References}

Aki, K. and Richards, P. G.: Quantitative seismology, 2nd Edn., University Science Books, 720 pp., 2002.

Ammon, J. C., Ji, C., Thio, H., Robinson, D., Ni, S., Hjorleifsdottir, V., Kanamori, H., Lay, T., Das, S., Helmberger, D., Ichinose, G., Polet, J., and Wald, D.: Rupture process of the 2004 SumatraAndaman earthquake, Science, 308, 1133-1139, 2005.

Arora, B. R. and Reddy, C. D.: Correlation between high electrical conductivity and seismicity: role of fluids, Ind. Geol. Congress, 1, 267-276, 2001.

Banerjee, P., Pollitz, F., Nagarajan, B., and Burgmann, R.: Coseismic Slip Distributions of the 26 December 2004 Sumatra- 
Andaman and 28 March 2005 Nias Earthquakes from GPS Static Offsets, Bull. Seis. Soc. Am., 97, S86-S102, 2007.

Bettinelli, P., Avouac, J., Flouzat, M., Jouanne, F., Bollinger, L., Willis, P., and Chitrakar, G. R.: Plate motion of India and interseismic strain in the Nepal Himalaya from GPS and DORIS measurements, J. Geodesy., 80, 567-589, 2006.

BIS: 1893-2002 (Part 1), Indian standard criteria for earthquake resistant design of structures, Part 1 - general provisions and buildings, Bureau of Indian Standards, New Delhi, 2002.

Bürgmann, R. and Dresen, G.: Rheology of the lower crust and upper mantle: evidence from rock mechanics, geodesy, and field observations, Annu. Rev. Earth. Planet. Sci., 36, 531-567, 2008.

Casarotti, E. and Piersanti, A.: Postseismic stress diffusion in Chile and South Peru, Earth and Planet Sci Lett., 206, 325-333, 2003.

Chlieh, M., Avouac, J. P., Hjorleifsdottir, V., Song, T. A., Ji, C., Sieh, K., Sladen, A., Hebert, H., Prawirodirdjo, L., Bock, Y., and Galetzka, J.: Coseismic Slip and Afterslip of the Great $M \mathrm{w} 9.15$ Sumatra-Andaman Earthquake of 2004, Bull. Seis. Soc. Am., 97, S152-S173, doi:10.1785/0120050631, 2007.

Kreemer, C., Blewitt, G., and Maerten, F.: Co- and postseismic deformation of the 28 March 2005 Nias Mw 8.7 earthquake from continuous GPS data, Geophys. Res. Lett., 33, L07307, doi:10.1029/2005GL025566, 2006.

Dasgupta, S., Mukhopadhyay, M., Bhattacharya, A., and Jana, T. K.: The geometry of the Burmese-Andaman subducting lithosphere, J. Seismol., 7, 155-174, 2003.

Deng, J., Hudnut, K., Gurnis, M., and Hauksson, E.: Stress loading from viscous flow in the lower crust and triggering of aftershocks following the 1994 Northridge, California, Earthquake, Geophys. Res. Lett., 26, 3209-3212, 1999.

Dickinson, W. R. and Seely, D. R.: Structure and stratigraphy of forearc regions, Am. Assoc. Petrol. Geol. Bull., 63, 2-31, 1979.

Dong, D., Fang, P., Bock, Y., Cheng, M. K., and Miyazaki, S.: Anatomy of apparent seasonal variations from GPSderived site position time series, J. Geophys. Res., 107, 2075, doi:10.1029/2001JB000573, 2002

Dziewonski, A. and Anderson, D. L.: Preliminary reference Earth model, Phys. Earth. Planet. Int., 25, 297-356, 1981.

Freed, A. M.: Earthquake triggering by static, dynamic, and postseismic stress transfer, Annu. Rev. Earth. Planet. Sci., 33, 335367,2005

Freed, A. M. and Burgmann, R.: Evidence of power-law flow in the Mojave Desert mantle, Nature, 430, 548-551, 2004.

Freed, A. M. and Lin, J.: Time-dependent changes in failure stresses following thrust earthquakes, J. Geophys. Res., 103, 24393 24409, 1998.

Freed, A. M. and Lin, J.: Delayed triggering of the $1999 \mathrm{Hec}-$ tor Mine earthquake by viscoelastic stress transfer, Nature, 449, 180-183, 2001.

Freed, A. M., Burgmann, R., and Herring, T.: Far-reaching transient motions after Mojave earthquakes require broad mantle flow beneath a strong crust, Geophys. Res. Lett., 34, L19302, doi:10.1029/2007GL030959, 2007.

Gahalaut, V. K., Nagrajan, B., Catherine, J. K., and Kumar, S.: Constraints on 2004 Sumatra-Andaman earthquake rupture from GPS measurements in Andaman-Nicobar Islands, Earth Planet. Sci. Lett., 242, 365-374, 2006.

Genrich, J. F., Bock, Y., MvCaffrey, R., Parawirodirdjo, L., Stevens, C., Puntodewo, S. S. O., Subarya, C., and Wdowinsky, S.: Distri- bution of slip at the northern Sumatran fault system, J. Geophys. Res., 105, 722-743, 2000.

Guilbert, J., Vergoz, J., Schissele, E., Roueff, A., and Cansi, Y.: Use of hydroacoustic and seismic arrays to observe rupture propagation and source extent of the mw 9.0 Sumatra earthquake, Geophys. Res. Lett., 32, L15310, doi:10.1029/2005GL022966, 2005.

Gutenberg, R. and Richter, C. F.: Frequency of earthquakes in California, Bull. Seis. Soc. Am., 34, 185-188, 1944.

Hearn, E. H.: Earthquakes: Shock delay, Nature, 411, 150-151, doi:10.1038/35075700, 2001.

Hearn, E. H.: What can GPS tell us about the dynamics of postseismic deformation?, Geophys. J. Int., 155, 753-777, 2003.

Hu, Y., Wang, K., He, J., Klotz, J., and Khazaradze, G.: Threedimensional viscoelastic finite element model for postseismic deformation of the great 1960 Chile earthquake, J. Geophys. Res., 109, B12403, doi:10.1029/2004JB003163, 2004.

Hughes, K. L. H., Masterlark, T., and Mooney, W. D.: Poroelastic stress-coupling between the M9.2 2004 Sumatra-Andaman and M8.7 2005 Nias earthquakes, Earth Planet. Sci. Lett., 293, 289299, 2010.

Jónsson, S.: Importance of post-seismic viscous relaxation in southern Iceland, Nat. Geosci., 1, 136-139, doi:10.1038/ngeo105, 2008.

Jónsson, S., Segall, P., Pedersen, R., and Björnsson, G.: Postearthquake ground movements correlated to pore-pressure transients, Nature, 424, 179-183, 2003.

Kayal, J. R., Gaonkar, S. G., Chakraborty, G. K., and Singh, O. P.: Aftershocks and seismotectonic implications of the 13 September 2002 earthquake ( $M \mathrm{w}$ 6.5) in the Andaman Sea Basin, Bull. Seism. Soc. Am., 94, 326-333, 2004.

King, G. C. P. and Cocco, M.: Fault interaction by elastic stress changes: New clues from earthquake sequences, Adv. Geophys. 44, 1-36, 2000.

King, G. C. P., Stein, R. S., and Lin, J.: Static stress changes and the triggering of earthquakes, Bull. Seismol. Soc. Am., 84, 935-953, 1994.

Lay, T., Kanamori, H., Ammon, C. J., Nettlers, M., Ward, S. N., Aster, R. C., Beck, S. L., Bilek, S. L., Brudzinski, M. R., Butler, R., DeShon, H. R., Ekstrom, G., Satake, K., and Sipkin, S.: The Great Sumatra-Andaman earthquake of 26 December 2004, Science, 308, 1127-1133, 2005.

Lin, J. and Freed, A. M.: Time-dependent viscoelastic stress transfer and earthquake triggering, Adv. Earth Sci. Mono., 2, 21-38, 2004.

Lombardi, A. M.: The Maximum Likelihood Estimator of $b$ Value for Mainshocks, Bull. Seismol. Soc. Am., 93, 2082-2088, doi:10.1785/0120020163, 2003.

Manga, M., Brumm, M., and Rudolph, M. L.: Earthquake triggering of mud volcanoes, Mar. Petrol. Geol., 26, 1785-1798, 2009.

McCaffrey, R., Zwick, P., Bock, Y., Prawirodirdjo, L., Genrich, J., Stevens, C., Puntodewo, S., and Subarya, C.: Strain partitioning during oblique plate convergence in northern Sumatra: geodetic observations and numerical modeling, J. Geophys. Res., 105, 28363-28375, 2000.

Mishra, O. P., Kayal, J. R., Chakrabortty, G. K., Singh, O. P., and Ghosh, D.: Aftershock Investigation in the Andaman-Nicobar Islands of India and Its Seismotectonic Implications, Bull. Seism. Soc., 97, S71-S85, 2007.

Mukhopadhyay, M.: Seismotectonics of subduction and back-arc 
rifting under the Andaman Sea, Tectonophysics, 108, 229-239, 1984.

Neilsen, C., Chamot-rooke, N., Rangin, C., and Andaman Cruise Team: From Partial to full strain partitioning along the IndoBurmese hyper-oblique subduction, Mar. Geol., 209, 303-327, 2004.

Nostro, C., Piersanti, A., and Cocco, M.: Normal fault interaction caused by coseismic and postseismic stress changes, J. Geophys. Res., 106, 19391-19410, 2001.

Okada, Y.: Internal deformation due to shear and tensile faults in a half-space, Bull. Seismol. Soc. Am., 82, 1018-1040, 1992.

Ortiz, M. and Bilham, R.: Source and rupture parameters of 31 December, 1881, Mw 7.9 Car Nicobar earthquake estimated from Tsunamis recorded in the Bay of Bengal, J. Geophy. Res., 108, 2215-2230, 2003.

Paul, J., Lowry, A. R., Bilham, R., Sen, S., and Smalley, J. R.: Postseismic deformation of the Andaman Islands following the 26 December, 2004 Great Sumatra-Andaman earthquake, Geophys. Res. Lett., 34, L19309, doi:10.1029/2007GL031024, 2007.

Peltzer, G., Rosen, P., Rogez, F., and Hudnut, K.: Post-seismic rebound in fault step-overs caused by pore fluid flow, Science, 273, 1202-1204, 1996.

Petroy, D. E. and Wiens, D. A.: Historical seismicity and inmplications for diffuse plate convergence in the northeast Indian Ocean, J. Geophy. Res., 94, 12301-12319, 1989.

Phinney, R. A. and Burridge, R.: Representation of the elasticgravitational excitation of a spherical Earth model by generalized spherical harmonics, Geophys. J. R. Astro. Soc., 34, 451-487, 1973.

Pollitz, F. F.: Postseismic relaxation theory on the spherical Earth, Bull. Seismol. Soc. Am., 82, 422-453, 1992.

Pollitz, F. F.: Gravitational-viscoelastic postseismic relaxation on a layered spherical Earth, J. Geophys. Res., 102, 17921-17941, 1997.

Pollitz, F. F., Burgmann, R., and Banerjee, P.: Post-seismic relaxation following the great Sumatra-Andaman earthquake on a compressible self-gravitating earth, Geophys. J. Int., 167, 397420, 2006.

Pollitz, F. F., Wicks, C. W., and Thatcher, W.: Mantle flow beneath a continental strike slip fault: Postseismic deformation after the 1999 Hector Mine earthquake, Science, 293, 1814-1818, 2001.

Reddy, C. D., Prajapati, S. K., and Kato, T.: A rheological model of post-seismic response due to 2004 Sumatra-Andaman earthquake: Contribution from low viscosity lithosphere, J. Earthq. Tsunami, 3, 25-34, 2009.

Reddy, C. D., Prajapati, S. K., and Sunil, P. S.: Co- and postseismic characteristics of Indian sub-continent in response to the 2004 Sumatra earthquake, J. Asian Earth Sci., 39, 620-626, doi:10.1016/j.jseaes.2010.04.019, 2010.
Rhie, J., Dreger, D., Burgmann, R. and Romanowicz, B.: Slip of the 2004 Sumatra- Andaman Earthquake from Joint Inversion of Long-Period Global Seismic Waveforms and GPS Static Offsets, Bull. Seis. Soc. Am., 97, S115-S127, 2007.

Rydelek, P. A. and Sacks, I. S.: Asthenospheric viscosity inferred from correlated land sea earthquakes in north east Japan, Geophys. J. Int., 336, 234-237, 1988.

Rydelek, P. A. and Sacks, I. S.: Asthenospheric viscosity and stress diffusion: a mechanism to explain correlated earthquakes and surface deformations in northeast Japan, Geophys. J. Int., 100, 39-58, 1990.

Savage, J. C. and Svarc, J. L.: Post-seismic deformation associated with the $1992 M w=7.3$ Landers earthquake, Southern California, J. Geophys. Res., 102, 7565-7577, 1997.

Scholz, C. H.: The Mechanics of Earthquakes and Faulting, Cambridge University Press, New York, 2003.

Schorlemmer, D., Wiemer, S., and Wyss, M.: Variations in earthquake-size distribution across different stress regimes, $\mathrm{Na}-$ ture, 437, 539-542, 2005.

Scott, M. W., Robert, T., and Kellogg, J. N.: Recent crustal deformation and the earthquake cycle along the Ecuador-Colombia subduction zone, Earth Planet. Sci. Lett., 216, 231-242, 2003.

Socquet, A., Vigny, C., Chamot-Rooke, N., Simons, W., Rangin, C., and Ambrosius, B.: Indian and Sunda plates motion and deformation along their boundary in Myanmar determined by GPS, J. Geophy. Res., 111, B05406, doi:10.1029/2005JB003877, 2006.

Stein, R. S.: The roles of stress transfer in earthquake occurrence, Nature, 402, 605-609, 1999.

Stein, R. S., King, G. C. P., and Lin, J.: Change in failure stress on the southern San Andreas fault system caused by the 1992 magnitude=7.4 Landers earthquake, Science, 258, 1328-1332, 1992.

Subba Rao, P. B. V.: Regional conductance map of Andaman and Nicobar region, Gondwana Research, 13, 387-410, 2008.

Subrahmanyam, C., Gireesh, R., Chand, S., Kamesh Raju, K. A. and Rao, D. G.: Geophysical characteristics of the Ninety east Ridge-Andaman island arc/trench convergent zone, Earth Planet. Sci. Lett., 266, 29-45, 2008.

Verma, R. K., Mukhopadhyay, M., and Bhu, N. C.: Seismicity, gravity and tectonics in the Andaman sea, J. Phys. Earth, 26 , S233-S248, 1978.

Wang, R. and Kümpel, H. J.: Poroelasticity: Efficient modelling of strongly coupled, slow deformation processes in a multilayered half-space, Geophysics, 68, 705-717, 2003.

Xiong, X., Shan, B., Zheng, Y., and Wang, R.: Stress transfer and its implication for earthquake hazard on the Kunlun Fault, Tibet, Tectonophysics, 482, 216-225, 2010.

Zhou, Y. H., Xu, L. S., and Chen, Y. T.: Source processes of the June 2000 southern Sumatra, Indonesia, Earthquake, Bull. Seismo. Soc. Am., 92, 2027-2035, 2002. 